\title{
Інституціональне забезпечення координованої реалізації податкової політики на сучасному етапі розвитку українського суспільства
}

\author{
(Представлено: д.держ.упр., проф. Драган І.О.)
}

\begin{abstract}
Досліджено інституціональне забезпечення координованої реалізації податкової політики на сучасному етапі розвитку украӥнського суспільства. В контексті розгляду изього питання охарактеризовано інституціонально-організачійне забезпечення реалізації податкової політики. Серед інститутів (організацій), які здійснюють реалізацію податкової політики, виокремлено такі органи влади - Міністерство фінансів України, Державну податкову службу Украӥни та ї̈ територіальні підрозділи.

Визначено основні пріоритети Міністерства фінансів України у забезпеченні формування та реалізації державної податкової політики, якими є: підвищення ефективності, стабільності та прогнозованості податкової системи; підвищення якості та ефективності податкового адміністрування; ефективне акумулювання ресурсів, необхідних для виконання державою своїх функцій; забезпечення справедливості та рівності податкової системи, ї̈ адаптацію до норм та правил Європейського Союзу; відсутність негативного впливу для ведення бізнесу та сприяння економічному розвитку; розширення бази оподаткування.

Розглядаючи сучасну організачійну структуру податкових органів, зазначено, що вона є досить громіздкою $і$ не забезпечує цүілісного інформачійного простору між організаціями та не відповідає принципам євроінтеграції.

З'ясовано, що однією з ефективних форм навчання податківців є підвищення кваліфікації, оскільки справлянням податків повинні займатися професійно підготовлені люди. 3 вище зазначеного доведено, щу створення та підтримання ефективної системи підвищення кваліфікаџії кадрів податкової служби є одним із пріоритетних напрямів ї̈ реформування.
\end{abstract}

Запропоновано иляхи удосконалення інституціонального механізму реалізації державної податкової політики, а саме встановлення: сфери компетенції та повноваження кожної посадової особи, вимог до посадових осіб у межах наданих повноважень; ідентифікації посадових осіб органів державної податкової служби на всіх електронних податкових документах, щуо надаються платникам податку (квитанціях, повідомленнях, листах, витягах), якщзо такі документи надходять із порушенням строків або обмежують платників податку в реалізації їхніх прав та обов'язків (зокрема блокують надання електронної звітності, податкових накладних, свідчать про затримання в реєстрації податкових накладних); чітких критеріїв оцінки діяльності служби та кожної посадової особи; відповідальність кожної посадової особи за порушення таких вимог.

Ключові слова: інституції; державна податкова політика; механізми державного управління; інституиіональний механізм; податкова система; податковий менеджмент; податкове адміністрування.

Постановка проблеми. Україна вкотре намагається вдосконалити податкову систему, яка $є$ механізмом наповнювання iї бюджету. Реформування відбувається на фоні проблем, пов'язаних зі збільшенням його видаткової складової через воєнні дії; боргами країни, які треба обслуговувати та сплачувати; необхідністю фінансувати соціальні гарантії та субсидії населенню; зростанням видатків Пенсійного фонду. Щодо наповнення дохідної складової бюджету також існують труднощі, спричинені зменшенням кількості підприємств, що реально працюють і збільшують ВВП країни, виробництвом сировини й сільськогосподарських товарів, додана вартість яких невисока порівняно з промисловими товарами.

Під час реформування економіки України відбувалась і відбувається досі зміна вже встановлених інституцій та створення нових інституційних форм. Проте часто внаслідок реформування, яке, зазвичай, спрямоване на підвищення ефективності національної економіки, з'являються стійкі неефективні інституції чи норми поведінки, які створюють головну небезпеку під час формування ефективного інституційного середовища. Для попередження таких негативних явищ нагальною постає проблема формування ефективного інституціонального забезпечення реалізації податкової політики України, основними складовими якого є: інституціонально-правове, інституціонально-організаційне та інституціонально-кадрове забезпечення реалізації податкової політики.

Аналіз останніх досліджень і публікацій. Питання податкової політики, іiі місце в державному регулюванні економічного розвитку розглядали такі зарубіжні вчені, як: Д.Рікардо, А.Вагнер, Дж.М. Кейнс, А.Лаффер, У.Петті, А.Сміт, Д.Черник та інші. У вітчизняній науці дослідженням стану податкової системи, 
ефективності податкової політики займалися вчені: В.Андрущенко, Ю.Волкова, О.Кудріна, С.Онишко, О.Ковалюк, М.Стецишин, Л.Тарангул, О.Тищенко. Однак в той же час інституціональне забезпечення координованої реалізації податкової політики на сучасному етапі розвитку українського суспільства досліджено недостатньо.

Метою статті $\epsilon$ дослідження питань інституціонального забезпечення координованої реалізації податкової політики на сучасному етапі розвитку українського суспільства.

Викладення основного матеріалу. Податкова політика передбачає відповідні інститути, через які вона реалізується і пристосовується до умов реформувань. Відтак інститут є суб'єктом інституційного механізму. Як зазначає Д.Норт, «... не існує інших рішень, крім використання інституційних механізмів, щоб установити правила гри, і використання організації - щоб забезпечити дотримання цих правил». Головною метою функціонування інституціонального механізму $\epsilon$ досягнення збалансованості податкової політики, що підтримується відповідними інституціональними структурами, у результаті чого нова модель такої політики повинна поєднувати забезпечення довгострокового прийнятного рівня заборгованості 3 достатнім рівнем короткострокової гнучкості.

За енциклопедичним словником 3 державного управління «організаційна структура управління» - це ієрархічно побудована за рівнями підпорядкованості сукупність структурних підрозділів організації та їх взаємозв'язків, що відображає розподіл відповідальності й повноважень на прийняття рішень. Відтак під структурною організацією чого-небудь необхідно розуміти його структурний устрій, пов'язаний із особливостями його внутрішньої організації (побудови). Таке визначення певною мірою відповідає поняттю «структурної організації органів державної податкової служби».

У контексті розгляду цього питання охарактеризуємо інституціонально-організаційне забезпечення реалізації податкової політики. Серед інститутів (організацій), які здійснюють реалізацію податкової політики можна виокремити такі органи влади - Міністерство фінансів України, Державну податкову службу України та іiі територіальні підрозділи.

Основними пріоритетами Міністерства фінансів України у забезпеченні формування та реалізації державної податкової політики є: підвищення ефективності, стабільності та прогнозованості податкової системи; підвищення якості та ефективності податкового адміністрування; ефективне акумулювання ресурсів, необхідних для виконання державою своїх функцій; забезпечення справедливості та рівності податкової системи, іiі адаптація до норм та правил Європейського Союзу; відсутність негативного впливу для ведення бізнесу та сприяння економічному розвитку; розширення бази оподаткування.

Державна податкова служба України є центральним органом виконавчої влади, діяльність якого спрямовується і координується Кабінетом Міністрів України через міністра фінансів. 3 метою забезпечення системного діалогу Державної податкової служби України з громадськістю функціонує Громадська рада при Державній податковій службі України.

Розглядаючи сучасну організаційну структуру податкових органів, варто зазначити, що вона $є$ досить громіздкою, що не забезпечує цілісного інформаційного простору між організаціями та не відповідає принципам євроінтеграції.

Щодо інституціонально-кадрової складової забезпечення реалізації податкової політики то варто зазначити, що кадрова політика Державної податкової служби до останнього часу демонструвала одіозні кадрові призначення на керівні посади в територіальних органах та в центральному апараті, безкарність посадових осіб органів податкової служби, особливо за корупційні діяння та у випадках порушення прав платників податків, високий рівень плинності кадрів, низький рівень оплати праці та фаховий рівень кадрів, недосконалу систему навчання та підвищення кваліфікації кадрів, а також неефективну систему управління персоналом. Низькі заробітні плати, відсутність певних соціальних гарантій сприяють розвитку корупції та не дозволяють залучати до роботи в службі високофахових працівників з певним набором моральних та професійних якостей, які б відповідали певним етичним стандартам. Відтак на сьогодні особливо актуальними є проблеми підготовки, перепідготовки, підвищення кваліфікації кадрів, а також їх добору та розстановки. Також особливої актуальності зараз набула проблема роботи з резервом управлінських кадрів, особливо керівних.

Однією з ефективних форм навчання податківців $є$ підвищення кваліфікації, оскільки справлянням податків повинні займатися професійно підготовлені люди. Виходячи 3 цього, створення та підтримання ефективної системи підвищення кваліфікації кадрів податкової служби є одним із пріоритетних напрямів її реформування.

Питання відповідальності та розмежування повноважень органів виконавчої влади та структурних підрозділів податкової служби є одними 3 тих, які потребують першочергового вирішення. На сьогоднішній день відсутнє чітке визначення центрів відповідальності за кожне прийняте рішення. Така відповідальність $є$ розмитою між Державною податковою службою України та Міністерством фінансів України. Фактично Державна податкова служба України значно впливає на рішення у сфері формування податкової політики, але де-юре формування податкової політики належить до сфери компетенції Міністерства фінансів України, що дає можливість службі кожного разу перекладати відповідальність за неякісні та хибні норми податкового законодавства на уряд та Верховну Раду України. 
Водночас зауважимо, що саме безкарність та безвідповідальність посадових осіб призводить до руйнування системи права, до систематичних порушень прав платників податків, до постійного недотримання контролюючими органами норм Податкового кодексу України та викривлення практики їх застосування.

На сьогоднішній день відсутній дієвий контроль діяльності Державної податкової служби зі сторони громадськості та бізнесу через небажання державних структур налагоджувати та будувати партнерські відносини з бізнесом, іiі закритість та реалізаціію політики, яка направлена виключно на поповнення бюджету. Відкритість податкової служби - це запорука зростання довіри до влади та можливість надати громадську, альтернативну офіційній, оцінку діяльності служби, а також перевести розгляд проблемних питань у публічне поле з приверненням уваги до них міжнародної спільноти.

Єдиним зі шляхів змінити ситуацію на краще є встановлення: сфери компетенції та повноваження кожної посадової особи, вимог до посадових осіб у межах наданих повноважень; ідентифікації посадових осіб органів Державної податкової служби на всіх електронних податкових документах, що надаються платникам податку (квитанціях, повідомленнях, листах, витягах), якщо такі документи надходять із порушенням строків або обмежують платників податку в реалізації їхніх прав та обов'язків (зокрема блокують надання електронної звітності, податкових накладних, свідчать про затримання в реєстрації податкових накладних); чітких критеріїв оцінки діяльності служби та кожної посадової особи; відповідальність кожної посадової особи за порушення таких вимог.

Оптимізація організаційної та функціональної структури податкових органів має передбачати: запровадження ефективної організаційної структури, що побудована за функціональним принципом, відновлення управлінської вертикалі Державної податкової служби, спрямоване на якісне та вчасне виконання органами покладених на них обов'язків; забезпечення підвищення аналітичної спроможності Державної податкової служби шляхом налагодження ефективного та своєчасного обміну інформацією, розширення використання інформаційних рішень, методів аналізу та обробки масивів даних, системи аналізу та управління ризиками у процесі виконання своїх функцій; мінімізацію впливу людського фактора та автоматизацію процесів під час виконання стандартизованих оперативних завдань, концентрацію ресурсів на інтелектуальних методах контролю і запобігання порушенням у сфері податкового законодавства; перегляд підходів до системи добору кадрів, розвитку вмінь та навичок співробітників, їх стимулювання і заохочення до доброчесного та ініціативного виконання обов'язків, які грунтуються на найкращих світових практиках. Пріоритизація кадрової політики на долученні кваліфікованих фахівців, вихованні працівників у сфері інформаційнотелекомунікаційних технологій та співробітників, задіяних у розробленні та застосуванні інтелектуальних методів контролю і запобіганні порушенням у сфері податкового законодавства; систематизацію та аналіз функцій Державної податкової служби і виважений підхід під час їх перерозподілу.

На нашу думку, модернізація податкової служби сприятиме: зменшенню управлінського апарату та здешевленню його утримання, рівномірному навантаженню на кожен підрозділ, сприятиме оперативному прийнятті рішень та підвищенню ефективності їх виконання.

Висновки. Отже, створення податкової системи і розробка податкової політики не можуть вестися спонтанно. Основне завдання державних органів полягає в тому, щоб створити дієвий податковий механізм впливу на поведінку господарюючих суб'єктів. Сучасна податкова система - продукт тривалої еволюції, що не в останню чергу зумовлювалася діями об'єктивних чинників, які проявлялися в процесі трансформації ролі держави.

Вдосконалення вітчизняного інституційного середовища за найкращими європейськими зразками сприятиме підвищенню ефективності та модернізації механізмів податкового регулювання для стимулювання соціально-економічного зростання.

\section{Список використаної літератури:}

1. Воронкова О. Організаційні засади податкового менеджменту / О.Воронкова // Науковий вісник Економіка, право. - Ірпінь. - 2015. - № 1 (28). - С. 104-109.

2. Ільяменко В. Податкова політика в системі регулювання соціально-економічного розвитку держави / В.Ільяшенко // Економіка та держава. - 2017. - № 8. - С. 22-24.

3. Касьяненко M. Організація роботи та управління органами державної податкової служби України / М.Касьяненко. - Ірпінь : Академія ДПС України, 2001. - 229 с.

4. Курносов О. Бюджетно-податкові інструменти як основа децентралізації влади в Україні / O.Курносов // Могилянські читання - 2015: досвід та тенденції розвитку суспільства в Україні: глобальний, національний та регіональний аспекти. - Миколаїв : ЧДУ ім. Петра Могили, 2015. - С. 37-40.

5. Мельтюхова Н. Реалізація державно-управлінських відносин на регіональному рівні / Н.Мельтюхова. - X. : ХарРI НАДУ «Магістр», 2016. - 180 с.

6. Приходченко Л. Забезпечення ефективності системи органів публічної влади: питання формулювання та вимірювання цілей / Л.Приходченко // Актуальні проблеми державного управління. - Одеса : ОРІДУ НАДУ.2008. - Вип. 2 (34). - С. 23-32.

7. Соколовська А. Особливості податкової системи України та напрями їі коригування / А.Соколовська // Фінанси України. - 2013. - № 9. - С. 28-44. 
8. Трофімова Л. Про гармонізацію та адаптацію законодавства України у сфері податкових правовідносин до законодавства Свропейського Союзу / Л.Трофімова // Фінансове право. - 2010. - № 1 (11). - С. 19-23.

\section{References:}

1. Voronkova, O. (2015), «Organizational principles of tax management», Ekonomika, pravo, No. 1 (28), pp. 104-109.

2. Il'jashenko, V. (2017), «Podatkova polityka v systemi reguljuvannja social'no-ekonomichnogo rozvytku derzhavy», Ekonomika ta derzhava, No. 8, pp. 22-24.

3. Kas'janenko, M. (2001), Organizacija roboty ta upravlinnja organamy derzhavnoi' podatkovoi' sluzhby Ukrai'ny, Akademija DPS Ukraïny, Irpin', 229 p.

4. Kurnosov, O. (2015), «Bjudzhetno-podatkovi instrumenty jak osnova decentralizacii' vlady v Ukrai'ni», Mogyljans'ki chytannja - 2015: dosvid ta tendenciï rozvytku suspil'stva v Ukrai'ni: global'nyj, nacional'nyj ta regional'nyj aspekty, ChDU im. Petra Mogyly, Mykolai'v, pp. 37-40.

5. Mel'tjuhova, N. (2016), Realizacija derzhavno-upravlins'kyh vidnosyn na regional'nomu rivni, HarRI NADU «Magistr», H., 180 p.

6. Pryhodchenko, L. (2008), «Zabezpechennja efektyvnosti systemy organiv publichnoï vlady: pytannja formuljuvannja ta vymirjuvannja cilej», Aktual'ni problemy derzhavnogo upravlinnja, ORIDU NADU, Odesa, No. 2 (34), pp. $23-32$.

7. Sokolovs'ka, A. (2013), «Osoblyvosti podatkovoi' systemy Ukrai'ny ta naprjamy i'i' koryguvannja», Finansy Ukrai'ny, No. 9, pp. 28-44.

8. Trofimova, L. (2010), «Pro garmonizaciju ta adaptaciju zakonodavstva Ukrai'ny u sferi podatkovyh pravovidnosyn do zakonodavstva Jevropejs'kogo Sojuzu», Finansove pravo, No. 1 (11), pp. 19-23.

Желай Олексій Вікторович - здобувач Міжрегіональної академії управління персоналом.

Наукові інтереси:

- теорія публічного управління;

- механізми державного управління;

- податкова політика.

https://orcid.org/0000-0001-7588-1728.

Стаття надійшла до редакції 06.02.2020. 